\title{
The Effectiveness of Cash For Work in Handling The Impact of COVID-19
}

\author{
Aprilya Fitriani \\ Institut Agama Islam Negeri (IAIN) Jember \\ Paper to be presented at the $4^{\text {th }}$ International Conference of Zakat (ICONZ) \\ 7-8 October 2020, Surabaya, Indonesia
}

\begin{abstract}
COVID-19 pandemic has an impact on all aspects of life, especially the economy. Economic activity has stopped causing a decrease in income and loss of employment, that vulnerable groups are affected by the COVID-19 pandemic. BAZNAS seeks to mitigate the impact of COVID-19 through the CFW program, an innovation in distributing zakat to vulnerable groups (mustahiq) affected by the COVID-19 pandemic. CFW program helped vulnerable groups, especially food needs. This paper tried to explain the implementation of BAZNAS CFW and to analyze the effectiveness of the program for mustahiq. The study was conducted using a qualitative approach through interviews and documentation methods. The BAZNAS CFW concept is unique, namely collective social empowerment, for mustahiq and Small Medium Enterprises (SMEs). The majority of participants who took part in the BAZNAS CFW program gave positive responses regarding the implementation and the impact it had given. That shows $C F W$ was effective in tackling the impact of the COVID-19 pandemic. The advantage of CFW is that it encourages the purchasing power of mustahiq towards economic needs, which can be purchased in the SMEs sector. This empowerment is not only for mustahiq, but also for the SMEs sector. CFW is beneficial for the social environment because it maintains and builds public facilities needed to prevent the spread of COVID-19. However, implementation in the short term is a disadvantage of $C F W$, meaning that economic improvements can not be seen in the short term. CFW is not a permanent employer program, but temporary work as a response to mitigating the impact of COVID-19.
\end{abstract}

Keyword : Cash For Work, COVID-19, Empowerment, Vulnerable Groups.

\section{INTRODUCTION}

Corona virus (COVID-19) was found in the city of Wuhan, China at the end of December 2019. Until the end of August 2020, it was confirmed that 216 countries had been infected with the coronavirus, including Indonesia, (The World Health Organization (WHO), 2020). COVID-19 spreads rapidly throughout the continent, so WHO declared the corona virus a global pandemic in March 2020. Indonesia responded to WHO appeal by implementing Large Scale Social Restriction (PSBB) to reduce the spread of the corona virus. The implementation of the PSBB caused economic activity to slow down to stop. The impact of PSBB implementation was felt by vulnerable groups. Slowing economic activity has resulted in decreased income and increased layoffs. That implications for increasing the number of poor people. In March 2020, the number of poor people was 26.42 million people, an increase of 1.63 million people compared to poverty in September 2019 of 24.79 million people, (BPS, 2020).

In mitigating the impact of the COVID-19 pandemic, BAZNAS divided the distribution scheme into two categories, namely the Special Distribution Program (consisting of Social-Economic and Health Emergency Management) and the Existing Security Program. In the Social and 
Economic Emergency Program, BAZNAS focused the program on fulfilling the family logistics package which aims to maintain family food security during implementation of the PSBB. In this program, BAZNAS innovates the utilization and distribution of zakat funds through the Cash For Work (CFW) Program, (BAZNAS Report in Handling The COVID-19 Pandemic, 2020).

Cash For Work (CFW) is a form of labor-intensive activity by providing direct wages to workers or volunteers who are involved in BAZNAS social activities. $\mathrm{CFW}$ is a program that involves mustahik in handling COVID-19. CFW involves informal workers affected by COVID-19 such as online drivers, public transportation drivers, participants of Small and Medium Enterprises (SMEs), and people with disabilities, to work with BAZNAS in social action. These informal workers are given wages for their work. CFW is carried out in various activities, namely Clean And Healthy Lifestyle (PHBS) education, spraying disinfectants in public facilities, and hand washing places in several shops managed by BAZNAS.

CFW was implemented by the BAZNAS Mustahik Economic Empowerment Institute (LPEM) from March to April 2020, with a target of 107 locations in Indonesia. The realization of the distribution of funds to the mustahiq amounted to 170 million rupiahs from Zakat funds. CFW has been implemented in 3 provinces, 10 cities, 59 sub-districts, and 77 villages, as well as in collaboration with 100 BAZNAS fostered shopp, (Laporan BAZNAS Dalam Penanganan COVID-19, 2020).

In the conditions of the COVID-19 pandemic, we are trying to explore the implementation of CFW carried out by BAZNAS and the effectiveness of CFW for vulnerable groups affected by the pandemic. This paper is structured as follows, section 2 describes an overview of the literature on the implementation of $\mathrm{CFW}$ in several countries, including
Indonesia. Section 3 provides details about the research methodology in analyzing the CFW phenomenon during the COVID-19 pandemic. Section 4 presents the results of our analysis. We analyze the effectiveness of the CFW program on mustahiq in strengthening their economies during a pandemic.

In the conditions of the COVID-19 pandemic, we are trying to explore the implementation of CFW carried out by BAZNAS and the effectiveness of CFW for vulnerable groups affected by the pandemic. This paper is structured as follows, section 2 describes a literature review on the implementation of CFW in several countries, including Indonesia. Section 3 describes the details of the research methodology in analyzing the CFW phenomenon during the COVID-19 pandemic. Section 4 presents the results of our analysis. We analyze the effectiveness of the CFW program on mustahiq in strengthening their economies during a pandemic.

\section{LITERATUR REVIEW}

Cash For Work (CFW) provides wages for unskilled and skilled workers to participate in social activities that can build or repair public infrastructure. Because payment is only received after the participants have completed work, CFW has often considered a type of conditional cash transfer (the "condition" is the completion of work). Implementation is usually limited to the short term (for example, one to two months) and payments can be made in the form of cash, vouchers, or electronic transfers. $\mathrm{CFW}$ is not an employment program. Its aim to provide short-term wages to vulnerable groups affected by the crisis or disaster, who have lost their jobs. The concept of CFW was originally designed to ease the psychological burden and boredom of people displaced by emergencies or disasters, and empower them to take responsibility for their own recovery. CFW 
was used when a program has the objective of improving public infrastructure or for the recovery of vulnerable groups affected by a disaster, (Mercy Corps, 2015). It is disaster recovery or social protection program, (Cfw \& Hunger, 2017).

Regarding natural disaster recovery, a study conducted by Doocy et al., (2006) on the Aceh post-tsunami CFW program used quantitative and qualitative approaches. The CFW program started on January 7 and ended on July 31, 2005. CFW was held in 60 villages with 18,000 participants. During the seven months of the program, total payments disbursed to workers amounted to USD 4.5 million. Payments to participants ranged from USD 1.02 (IDR 10,000) to USD 7.65 (IDR $75,000)$ per day, depending on the type and skill level of the work, the length of the working day, and the length of the project. The resulting output from the CFW program for land clearing covers an area of 136 square kilometers, 262 kilometers of roads, and 2,006 buildings. Construction of 306 permanent buildings and 577 temporary buildings, including mosques, schools, and temporary houses. Participation in the CFW program was not to interfere with initial work or other priorities, because of personal needs (only those who need income will participate in CFW), and because of the program's flexibility, CFW participants can decide how many days per week they want to be involved in the program.

A study by Personal And Archive (2011) analyzed post-earthquake food insecurity in Haiti, using a quantitative approach and survey methods. The results show that the CFW program was not considered to be on target in providing benefits to the poor. This program did not give priority to household members affected by the earthquake in the form of homelessness.

Another study was conducted by Nagamatsu, (2014) to see the effectiveness of CFW in nuclear disaster recovery in
Japan, using a quantitative approach. The findings show that $40 \%$ of participants still rely on their work as their main source of income. Besides, work experience was valued in the CFW program. The participants were satisfied with the CFW program.

Regarding emergencies and social protection, a study conducted by Guluma (2004) in the poor areas of Masisi Plateau and Blito in Congo, used focus group discussion method. CFW activities include road and school rehabilitation. Most of the CFW beneficiaries use it to buy household necessities such as salt, soap, palm oil, dried fish, and clothes for their families. Another benefit of the program is that beneficiary households can buy certain assets such as livestock. Wives also take out small loans. This means they can invest in small businesses, such as renting land to supplement their income.

A study conducted by Jones, (2004) on the impact of the $\mathrm{CFW}$ program in Hazarat, Afghanistan, used a qualitative approach. The CFW program was chosen to reduce the impact of the humanitarian situation that occurred in Hazarat, in particular, to protect people's livelihoods. Some of the activities carried out include building water reservoirs, building protective walls, planting trees, collecting and planting animal feed, and embroidery projects for women. The program duration was 70 working days to helped people earn income, with 2 Euros per day for unskilled workers and 4 Euros per day for skilled workers. The analysis shows that $90 \%$ of the income is used to buy food and not to build assets. The main food items purchased are wheat, tea, sugar, and cooking oil.

Latif (2009) has evaluated the implementation of the CFW program in Palestine, used quantitative and qualitative approaches. The findings show that during the two months the CFW project managed to create 219 temporary jobs for the poor, and this became their livelihood in the short 
term. Other benefits of this program include increasing community assets, developing public infrastructure such as repairing roads and planting trees.

A study conducted by Brewin (2009) focused on the impact of CFW on households and public services, using a qualitative approach. The findings show that there is an improvement in the health sector by $9 \%$, education by $19 \%$, food security by $19 \%$, and the value of household assets by $10 \%$.

A study conducted by MascieTaylor et al., (2010) to analyze the effectiveness of the CFW program on improving the nutrition of women and children, during the annual food insecurity period in Bangladesh, using a quantitative approach. The findings show that the CFW program leads to greater household food expenditure and consumption, and the nutritional status of women and children increases.

A study conducted by Chen (2014) focused on the CFW policy applied in mountainous areas of the Beijing municipality, using a survey method. The findings show that, based on the household level, poor households are empirically more likely to participate in the CFW program, whereas based on the individual level, people with lower chances (eg elderly, women, less educated people) are forest rangers. In the short term, CFW provides additional income for poor households. Long-term benefits depend on the CFW program's ability to increase farmers' savings, as well as the opportunities to generate new sources of income.

A recent study was conducted by Hidayah And Mukhlis (2019) on the effectiveness of CFW on the use of village funds for access to clean water and sanitation, using a quantitative approach. The study was conducted in 405 districts and 810 rural area observations in 2014 and 2016. The results of the analysis show that the CFW program has no impact on the people who work in the formal sector. However, CFW affected people working in the informal sector by 0.77 percent for clean water projects and 5.47 percent for sanitation projects.

(Abebe, 2020) conducted a study on food insecurity in Southern Ethiopia using quantitative and qualitative approaches. The aim is to explore the challenges and prospects of CFW and Food For Work (FFW) in building household resilience to food insecurity in the Boricha District of Southern Ethiopia. Findings show that the CFW and FFW programs have little benefit in increasing food security. The analysis shows that a human rights-based approach to social protection is necessary because social protection is an inherent social right of humans, rather than as a charity for the beneficiaries.

From a theoretical perspective, the development of the CFW policy model was developed by (Basu, 1996) to find out the best policy - whether assisting in the form of food or cash, by building a theoretical model through economic functions. The analysis concluded that the $\mathrm{CFW}$ program will increase demand for food, cause food prices to rise, and have the opportunity for wage earners to buy food. However, those who do not participate in this program - for example the old and the weak, will be worse off.

A study conducted by Missaglia And Boer (2010) on the implications of CFW and FFW policies on emergency assistance in Palestine. The simulation of the impact of various policies is carried out using the CGE (Computer Generalized Equilibrium) model. The model analysis produces two approaches, the first is called a 'welfare-oriented' approach : by providing the largest subsidies for sectors that produce goods that dominate household consumption, namely food, manufacturing, private services, and public services. Second, the 'labor-oriented' approach : giving the largest sub-sectors to laborintensive sectors, namely trade, 
construction, transportation, and public services. They argue that a 'labor-oriented' approach is preferable to a 'welfareoriented' approach which only provides subsidies for sectors that produce household consumption goods.

A study was conducted by Janen Dan Sivakumar (2014) to find a model for implementing the CFW program in postemergency situations in Sri Lanka, using the focus group discussion method. The findings show that the implementation of the CFW program for post-emergency situations in Srilankan is more appropriate using the Generalized Model. This model would provide a basic implementation framework for the implementation of the CFW program in the future. This model would facilitate the improvement of the economic and social standards of communities sustainably affected by disasters.

\section{METHODOLOGY}

This paper used a qualitative approach with a semi-structured interview method. Qualitative methods are considered as the best way to get a clear and deep understanding of the phenomenon, (Eldabi et al., 2002). The interview is one way to achieve research objectives. The aim is to find out the process of implementing CFW and to analyze the effectiveness of CFW for participants. Interviews allow participants to express their views on certain phenomena, (Mohd et al., 2015). Written documents are also used to obtain data to complement the results of interviews. Because written documents are a source of qualitative data (Eldabi et al., 2002).

The sample selection is based on purposive sampling. Purposive sampling is one way of determining the sample in a qualitative approach, namely determining which group of participants to be sampled according to the criteria relevant to the focus of the study. In this study, participants were selected based on their participation in the CFW program, organized by BAZNAS in Bogor and Jakarta city.

The number of research samples is very important to determine the results of the study following the research objectives. Data saturation techniques are used in sampling to avoid data replication or redundancy (Umar et al., 2019). The number of participants was determined based on the opinion of Morse (1994), who recommended six participants for a qualitative study. Based on the data saturation guidelines, the sample used was six respondents because it was realized that each increase in the sample would cause redundancy or data replication (Umar et al., 2019). The same number of respondents was also used by another researcher, (Ahmed, 2002). He revealed that using a small sample to analyze the focus of the study was sufficient to achieve the research objectives.

Table 1. Profil Interviewees

\begin{tabular}{clcccc}
\hline No & \multicolumn{1}{c}{ Profession } & Gender & Age & Type of Labor & Code \\
\hline 1 & Washing and ironing labor & Female & 55 & Unskilled worker & P1 \\
\hline 2 & Coffee seller & Male & 41 & Unskilled worker & P2 \\
\hline 3 & Online driver & Male & 35 & Unskilled worker & P3 \\
\hline 4 & Online driver & Male & 53 & Unskilled worker & P4 \\
\hline 5 & Online driver & Male & 55 & Unskilled worker & P5 \\
\hline 6 & Food seller & Female & 49 & Unskilled worker & P6 \\
\hline
\end{tabular}

Source : Author's interview (2020) 
Table 1 shows the profile of the interviewees of 6 respondents. Respondents consisted of four men and two women aged 35 to 55 years. The majority of respondents are unskilled workers. We classified respondents into three criteria: labor, driver, seller. First, respondents who work as laborers, namely washing and ironing labor (P1). Second, three respondents who work as drivers, namely online drivers (P3, P4,
P5). Finally, two respondents work as sellers, namely coffee sellers (P2) and food sellers (P6).

Interviewees are interviewed based on interview guidelines that have been prepared to achieve research objectives. Table 2 shows the themes and types of questions addressed to the interviewee.

Table 2. Interview Guidelines

\begin{tabular}{cll}
\hline No & \multicolumn{1}{c}{ Theme } & \multicolumn{1}{c}{ Interview Questions } \\
\hline 1 & Existing program & What program did you follow? \\
\hline 2 & Program activities & What did you do in this program? \\
\hline 3 & Program benefit & What did you get from this program? \\
\hline 4 & Program impact & $\begin{array}{l}\text { How was the program helped you during the COVID-19 } \\
\text { pandemic? }\end{array}$ \\
\hline
\end{tabular}

Source : Author (2020)

\section{RESULT}

\section{Existing Program}

Interviewees were asked about their views on the CFW program organized by BAZNAS. In general $(n=6)$, the participants understood the program they were participating in. Following responses of the participants :

I volunteered for BAZNAS in Bogor. I was told to work first, so volunteered first $[\ldots]$ and then I was given a voucher $[\ldots](\mathrm{P} 1)$.

I forgot the name of the program, I just became a volunteer, I joined the work [....] When I worked, I would be given a salary. (P2)

I joined the CFW program, the program has BAZNAS. The concept is that we become volunteers to prevent the spread of COVID-19 [...] after that we get vouchers that can be exchanged for groceries. So we work first, the first volunteer for the community, after that we are given food vouchers. (P3)

[...] I work as a volunteer for the prevention of COVID-19 in the community, and then I am given a voucher $[. .].(\mathrm{P} 4)$.

We remind the public about the dangers of COVID [...]. When finished, they are given food vouchers $[\ldots]$ (P5).

[...] Become a volunteer [...] and will be given a voucher to be exchanged for basic food ingredients (P6).

Based on these findings, the majority of participants understood the concept of implementing CFW. However, the majority forgot the name of the program that was followed. In general, the participants can understand the concept of $\mathrm{CFW}$ correctly, this program is intended to help mustahiks whose income has decreased due to the impact of the COVID19 pandemic. One of the functions of the CFW program is short-term recovery from disasters. This finding is supported by previous studies, namely Doocy et al (2006) and Namagatsu (2014).

\section{Program Activities}

Interviewees were asked about the activities carried out in this program. All participants $(n=6)$ were known the activities that must 
be done in the CFW program. Following responses of the participants:

We spray disinfectants in several public facilities [....]. (P1)

[...] Distributing masks to road users, so they don't forget to wear masks to protect against the spread of COVID-19. (P2)

Become a volunteer for a Clean and Healthy Lifestyle (PHBS), providing explanations to the public about preventing the spread of COVID-19. (P3)

I installed handwashing [...] so people remember to keep their hands clean during the pandemic season. $(\mathrm{P} 4)$

We spray disinfectants, so public places are free from the coronavirus. (P5)

I distribute boxed rice to people who iftar meal $[\ldots]$. (P6)

Based on these findings, the majority of activities carried out by the participants were to prevent the spread of COVID-19. It shows that one of the CFW activities is based on social protection for communities affected by disasters. This finding is supported by a study conducted by (Latif, 2009).

\section{Program Benefit}

Participants were interviewed about the benefits of the CFW program during the COVID-19 pandemic. Participants $(n=4)$ consciously participated in the CFW program to reduce economic difficulties caused by the implementation of the PSBB. Following responses of the participants:

I appreciate Cash For Work program. Apart from protecting the environment, the provision of basic needs helps families whose income has been greatly reduced due to the COVID-19 pandemic. (P2)

Alhamdulillah, BAZNAS has trusted me to distribute masks and gave the wages were useful to feed my family. (P3)

This program can help my wife cook rice at home because my income has dropped dramatically since the pandemic. (P4)
I can provide groceries to my wife so the children can keep eating. (P5)

Based on these findings, the impact of CFW is felt in the economic sector. CFW is sufficient for household food needs, that participate in the CFW program. CFW helps household welfare in the short term. This finding was supported by a study conducted by (Janen \& Sivakumar, 2014)

\section{Program Impact}

Participants were interviewed about implementation of the CFW program in helping participants during the COVID-19 pandemic. They $(n=3)$ revealed that $C F W$ provides a solution to the economic crisis during a pandemic. Following responses of the participants:

Income decreased. Access to the coffee shop is closed. Factory employees who became customers were now on vacation. So that I get no income. After becoming a BAZNAS volunteer, I saw that the work was not too hard and that I received wages that could be exchanged for basic needs. This program helps me and my family who are currently having a minus income. (P2)

During the COVID-19 pandemic, my income decreased [...] I was confused about how to provide for my family at home. When I found out that there was a CFW program, I got the information so I could participate. This program helps our economic needs. I hope that CFW can continue during the COVID-19 pandemic. (P3)

So volunteering to help my family's economic needs [...] I am not confused about buying rice, because I get basic need from volunteering. Programs like this are very helpful for poor families like us. (P5)

Based on these findings, implementation of the CFW program is a solution to economic difficulties during the COVID-19 pandemic. Through CFW, vulnerable people receive assistance by utilizing their manpower or skills for social purposes. However, one of the 
disadvantages of $\mathrm{CFW}$ is that it is shortterm, to increase income, vulnerable people start looking for additional new sources of income. This finding was supported by (Chen, 2014).

\section{DISCUSSION}

\section{Role of Zakat in Mitigating the Impact of COVID-19.}

Islamic social finance, which has been predicted as an alternative solution in the national economy, was required to adapt to utilizing and distributing funds to support the government in mitigating the impact of the COVID-19 pandemic. One of the Islamic social finances has large potential in Indonesia is zakat. The potential for zakat in Indonesia was projected to reach 233.8 trillion rupiahs, although until 2019 the realization of zakat collection is only around 10 trillion rupiahs (Indonesia Zakat Outlook, 2020).

During a crisis, the spirit of sharing and the interest in donating from the Indonesian people has increased, including during the COVID-19 pandemic. In various regions, people were moved to help each other and build solidarity to mitigate the impact of the pandemic, in synergy with government programs. In responding to the COVID-19 pandemic, BAZNAS focuses on the utilization and distribution of zakat funds to two focuses, namely: distribution programs and security existing programs. For the Distribution Program, BAZNAS has focused on the distribution of ZIS funds, into two more specific and needed programs in dealing with impacts caused by COVID-19, namely health emergency program and socio-economic emergency program. The total distribution fund for the BAZNAS COVID-19 program reached 44 billion rupiahs, including zakat distribution for the CFW program of 671.6 million rupiahs, (Situation Report on Handling Pandemic COVID-19, 2020).

\section{Innovations in Tackling the COVID-19 Pandemic}

Cash For Work (CFW) is BAZNAS's innovation in distributing zakat funds to mustahiq. Distribution is carried out through empowering vulnerable groups to carry out social actions, then receiving wages as a form of their participation. BAZNAS empowers mustahiq - skilled labor and unskilled labor - to volunteer for activities to prevent the spread of COVID19. Through CFW, the community plays a role in protecting the environment and increasing social awareness. CFW helps vulnerable groups who have lost their jobs as a result of the disaster, to find temporary work, and provide for household needs. CFW was expected to be a stimulus for other institutions to raise social awareness when the COVID-19 pandemic occurs in many countries.

BAZNAS divides CFW into three groups. Each group has different targets, objectives, and payment systems. The grouping is based on mustahik affected by the COVID-19 pandemic, they are unable to fulfill their daily needs because they have lost their source of income. These groups are the Vulnerable Group, Small Medium Enterprise (SMEs) Group, and Disability Group. Vulnerable Group is a CFW aimed at vulnerable people so they can protect themselves from poverty, prevent crime and social inequality in society. SMEs Group is a CFW aimed at SME participants so that they can meet their economic needs during the decline in business turnover. Disability Group is a CFW aimed at people with disabilities, tailored to the skills they can perform. Table 3 shows the CFW program targets classified into three groups. 
Tabel 3. BAZNAS CFW Program Group

\begin{tabular}{llll}
\hline \multicolumn{1}{c}{ Groups } & \multicolumn{1}{c}{ Target } & \multicolumn{1}{c}{ Goal } & \multicolumn{1}{c}{ Payment } \\
\hline $\begin{array}{l}\text { Vulnerable } \\
\text { Group }\end{array}$ & $\begin{array}{l}\text { - Vulnerable economic } \\
\text { groups (for example online } \\
\text { drivers, public } \\
\text { transportation drivers, } \\
\text { laborers, street singers, } \\
\text { etc.) }\end{array}$ & $\begin{array}{l}\text { - } \begin{array}{l}\text { Protect yourself from } \\
\text { poverty, prevent crime } \\
\text { and social inequality }\end{array} \\
\text { - }\end{array}$ & $\begin{array}{l}\text { - Compensation } \\
\text { in cash }\end{array}$ \\
\hline SMEs Group & $\begin{array}{l}\text { SMEs participants (for } \\
\text { example food sellers, } \\
\text { tailors, etc.) }\end{array}$ & $\begin{array}{l}\text { - Able to meet the needs } \\
\text { of the economy during } \\
\text { the decrease in profit }\end{array}$ & $\begin{array}{l}\text { - Compensation } \\
\text { in basic needs }\end{array}$ \\
\hline Disability Group & - Disability group & $\begin{array}{l}\text { Jobs that match their } \\
\text { expertise, paying } \\
\text { attention to length and } \\
\text { workload }\end{array}$ & $\begin{array}{l}\text { Access } \\
\text { marketing and } \\
\text { other relevant } \\
\text { assistance }\end{array}$ \\
\hline
\end{tabular}

Source : BAZNAS Report on Handling Pandemic COVID-19, 2020.

\section{Implementation of Cash For Work}

Implementation of the $\mathrm{CFW}$ program by BAZNAS is unique compared to the CFW program implemented in several countries. This uniqueness is based on collective social empowerment, not only for mustahiq, but also for small and medium enterprises. BAZNAS collaborates with a partner store, namely Zmart. Zmart's function in the $\mathrm{CFW}$ program is as a grocery distributor for CFW participants. Unlike other countries that give cash to participants after completing CFW activities, BAZNAS provides participants with vouchers, which can be exchanged for basic need packages available at Zmart. Zmart is an economic empowerment program to increase the existence and capacity of UKM. The food vouchers that were distributed were worth 200 thousand rupiahs which could be exchanged for various food needs of the participants. The target of economic empowerment is not only the mustahiq, but also SME players who during the COVID-19 pandemic experienced a drastic decrease in income.
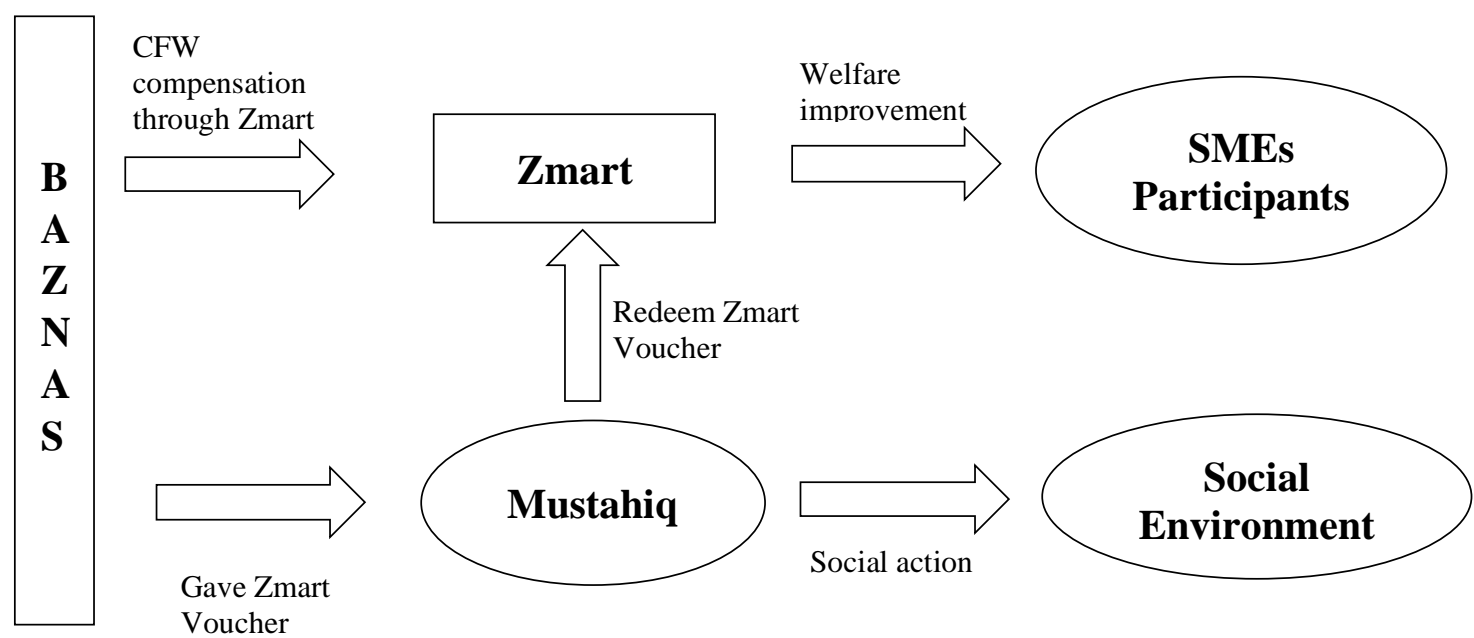

Figure 1. CFW Implementation Scheme

Source: Laporan BAZNAS Dalam Penanganan COVID-19, modified by Author 


\section{Effectiveness of the CFW Program}

In general, CFW aims for disaster relief programs. It has a psychological impact on the participants to return to their activities and think positively. This has a positive effect to start looking for new sources of income, because of losing a previous job. Of the participants we interviewed, the majority appreciated the CFW program, for helping its economy and participating in social action that benefits society.

Providing vouchers or cash transfers will increase people's purchasing power for household needs. When purchasing power increases, market will accept customer demand. So that economic activity will run. If this continues, the negative impact of the COVID-19 pandemic on the economy will gradually decline until it disappears completely. Therefore, the success of CFW becomes a benchmark in asset development and household economy. Table 4 shows the advantages and disadvantages of the CFW program.

Table 4. Advantages and Disadvantages of CFW Program

\begin{tabular}{|c|c|}
\hline Advantages & Disadvantages \\
\hline $\begin{array}{l}\text { - Empowerment - empowerment of mustahiq and } \\
\text { small and medium enterprises through useful } \\
\text { social activities }\end{array}$ & $\begin{array}{l}\text { Duration - implementation of the program } \\
\text { in the short term, two weeks or two months, } \\
\text { the impact of the economic recovery is less } \\
\text { visible }\end{array}$ \\
\hline $\begin{array}{l}\text { - Economic recovery - increasing the purchasing } \\
\text { power of mustahiq on household needs }\end{array}$ & $\begin{array}{l}\text { Participants - elderly, children, sick people } \\
\text { cannot participate in this program }\end{array}$ \\
\hline $\begin{array}{l}\text { SME development - encouraging the } \\
\text { purchasing power of mustahiq among SMEs }\end{array}$ & $\begin{array}{l}\text { High Administration Cost - requires high } \\
\text { costs for monitoring and evaluation }\end{array}$ \\
\hline $\begin{array}{l}\text { Repair (or make) public facilities - social } \\
\text { activities aimed at public facilities and } \\
\text { infrastructure so that they benefit the } \\
\text { community }\end{array}$ & $\begin{array}{l}\text { Not a permanent job - not a job that } \\
\text { provides fixed wages, but a temporary job } \\
\text { as a response to disaster recovery }\end{array}$ \\
\hline
\end{tabular}

Source: Author, 2020

\section{CONCLUSION}

COVID-19 pandemic has an impact on all aspects of life, especially the economy. The economy stopped due to the implementation of the PSBB which caused a decrease in income and even loss of employment. Unemployment is increasing and vulnerable groups are affected by the COVID-19 pandemic. To reduce the impact of the pandemic, the government has implemented various policies for national economic recovery as a means of helping economically vulnerable groups. BAZNAS through the CFW program synergizes with the government in mitigating the impact of the spread of COVID-19 in the health, economy, and existing programs.
CFW helps vulnerable groups in their daily food needs. BAZNAS divides the CFW program into three groups, that are Vulnerable Group, Small Medium Enterprise (SMEs) Group, and Disability Group. Each group has different targets and payment systems. The same goal was to helped vulnerable groups such as online drivers, food sellers, laborers, disabilities, and SMEs, for household needs especially food needs, on handling COVID-19 pandemic. The CFW concept initiated by BAZNAS is collective empowerment, not only empowering mustahiq, but also empowering the SME sector, through Zmart, so purchasing power increases and economic activity resumes. 
Majority of the participants who took part in the BAZNAS CFW program gave a positive response regarding the implementation and impact. This shows that CFW is effective in tackling the impact of the COVID-19 pandemic. The advantage of $\mathrm{CFW}$ is it encourages the purchasing power of mustahiq towards economic needs, which can be obtained in the SME sector. Empowerment is not only for mustahiq, but also empowers the SME sector. CFW program also beneficial for the social environment because it maintains and builds public facilities needed to prevent the spread of COVID-19. However, implementation in the short term is a disadvantage of $\mathrm{CFW}$, meaning that economic improvements can not be seen in the short term benefits. Besides, CFW is not a permanent employer program, but rather temporary work as a response to mitigating the impact of COVID-19.

\section{REFERENCES}

Abebe, G. (2020). Cash-for-work and foodfor-work programmes' role in household resilience to food insecurity in southern Ethiopia. Development in Practice, O(0), 1-14. https://doi.org/10.1080/09614524.20 20.1747398

Ahmed, H. (2002). Financing Micro Enterprises : An Analytical Study of Islamic Microfinance Institutions .pdf. 9(2).

Amil, B., \& Nasional, Z. (n.d.). baznasindonesia badanamilzakat www.baznas.go.id (021) 222333 555. 021 .

Basu, K. (1996). Relief programs: When it may be better to give food instead of cash. World Development, 24(1), 9196. https://doi.org/10.1016/0305750X(95)00110-X

BAZNAS. (2020). Laporan BAZNAS Dalam Penanganan COVID-19.
Jakarta : Puskas BAZNAS

Brewin, M. (2009). GERMAN AGROACTION KENYA EVALUATION OF CASH COMPONENT OF WHH / GAA PROJECT No . KEN 1067 Mitigation of Drought Impact through WASH and Cash for Work in Highly Affected ASAL Areas of Eastern Kenya. May.

Cfw, S. W. M., \& Hunger, A. A. (2017). Guidelines for Implementing Cashfor-Work Projects in the Waste Management Sector. November.

Chen, Y. (2014). Pro-rural Policies, Income, and Inequality: Evaluating a Cash-for-Work Program in Rural China https://doi.org/10.1162/ASEP

Doocy, S., Gabriel, M., Collins, S., \& Robinson, C. (2006). Implementing cash for work programmes in posttsunami Aceh: experiences and lessons learned. 30(December 2004), 277-296.

Eldabi, T., Irani, Z., Paul, R. J., \& Love, P. E. d. (2002). Quantitative and qualitative decision making methods in simulation modelling. Management Decision, 40(1), 64-73. https://doi.org/10.1108/00251740210 413370

Guluma, Y. (2004). Cash for work projects: a case study in the Democratic Republic of Congo. http://www.odi.org.uk/resources/libr aries/cash-vouchers/drc_scf.pdf

Hidayah, I., \& Mukhlis, I. (2019). Dana Desa on Clean Water and Sanitation Access in Indonesia: Does Cash-forWork (Pkt) Matter? August, 104-114. https://doi.org/10.20472/efc.2019.01 2.008

Janen, S. ., \& Sivakumar, S. . (2014). Implementation of Cash for Work Program for Post Disaster Emergency Recovery Process Based on Experience in Post War 
Resettlement Process through Emergency Northern Recovery Project of Sri Lankan. 03(10).

Jones, B. (2004). Cash for Work project in Hazarajat. May.

Center of Strategic Studies. (2020). Indonesia Zakat Outlook. Jakarta : The National Board of Zakat

Latif, M. A. (2009). External Evaluation CASH FOR WORK PROJECT. 00972(November).

Mascie-Taylor, C. G. N., Marks, M. K., Goto, R., \& Islam, R. (2010). Impact of a cash-for-work programme on food consumption and nutrition among women and children facing food insecurity in rural Bangladesh. Bulletin of the World Health Organization, 88(11), 854-860. https://doi.org/10.2471/BLT.10.0809 94

Mercy Corps. (2015). TRANSFER PROGRAMMING toolkit PART I: CASH TRANSFER METHODOLOGY GUIDE.

Missaglia, M., \& Boer, P. De. (2010). Food-For-Work versus Cash-ForWork: Emergency Assistance in Palestine Food-For-Work versus Cash-For-Work: Emergency. April 2015 , 37-41. https://doi.org/10.1080/09535310420 00304254

Mohd, S., Noor, N., \& Hashim, A. (2015). CSR and Sustainability of Islamic Banking: The Bankers View (CSR dan Kemampanan Perbankan Islam: Pandangan Pegawai Bank). Jurnal Pengurusan, 45(2015), 73-81. http://ejournals.ukm.my/pengurusan/ article/viewFile/12181/4146

Morse, J.M. (1994), "Designing funded qualitative research", in Denzin N.K. and Lincoln Y.S. (Eds),

Handbook of Qualitative Research, Sage Publications, Thousand Oaks, CA, pp. $220-235$

Nagamatsu, S. (2014). Are Cash for Work ( $C F W$ ) programs effective to promote disaster recovery? 2011 Fukushima Daiichi Nuclear Power Plant Accident. 9(2), 161-175.

Personal, M., \& Archive, R. (2011). Munich Personal RePEc Archive Who Benefit from Cash and Foodfor-Work Programs in Who Benefit from Cash and Food-for-Work Programs in. 35661.

Situation Report on Handling Pandemic COVID-19, 2020

Studies, S., National, T. H. E., \& Of, B. (2020). OUTLOOK.

Umar, U. H., Ado, M. B., \& Ayuba, H. (2019). Is religion (interest) an impediment to Nigeria's financial inclusion targets by the year 2020?: A qualitative inquiry. Qualitative Research in Financial Markets, 12(3), 283-300. https://doi.org/10.1108/QRFM-012019-0010

World Health Organization (WHO). (2020). Weekly Operational Update on COVID-19, 21 August 2020. June, $1-10$

Aprilya Fitriani

Institut Agama Islam Negeri (IAIN)

Jember

aprilya.fitriani@iain-jember.ac.id 